\title{
Implementasi Virtual Reality Pada Tur Virtual Monumen Nasional Menggunakan Unity 3D Algoritma Greedy Berbasis Android
}

\author{
Ilham Rizaldy ${ }^{1}$, Ina Agustina ${ }^{2}$, Fauziah ${ }^{3}$ \\ 1.ilhamrizaldy@gmail.com, ${ }^{-2}$.ina.agustina@ civitas.unas.id, ${ }^{-3}$ fauziah@civitas.unas.ac.id
}

Program Studi Teknik Informatika, Fakultas Teknologi Komunikasi dan Informatika Universitas Nasional

\begin{abstract}
Abstrak - The museum is one of the most popular tourist destinations. Every attraction of the museum will be of course the history of various objects scattered in the tourist area, so that tourism is obliged to provide information about the location of the National Monument Museum, and manual process is still less interactive so as to provide the opportunity to create $3 D$ virtual tours applications on android-based smartphone, which can help provide information such as maps on tourists. Sites and attractions that exist in the tourist area with $3 D$ virtual display. $3 D$ models of every tourist tourist location created by using the Blender 3D Modeling app, appear in apps created with Unity $3 D$ Engine. Software Engineering Process (RPL) prototyping model which is the methodology used in this research. The result of the application allows users to know the history and buildings in the National Monument Musem, and travelers can explore $3 D$ virtual by using android based smartphone.
\end{abstract}

Keywords - National Monument, Virtual Tourists, Android, Virtual Reality, Unity.

Abstrak - Museum merupakan salah satu tujuan wisata
yang paling diminati. Setiap daya tarik museum akan
sejarah tentu memiliki berbagai objek yang tersebar di
kawasan wisata, sehingga pariwisata berkewajiban
memberikan informasi mengenai tentang lokasi Museum
Monumen Nasional, dan proses manual masih kurang
interaktif sehingga memberikan kesempatan untuk
membuat aplikasi virtual tours 3D pada smartphone
berbasis android, yang bisa membantu memberikan
informasi seperti peta pada turis. Situs dan atraksi yang
ada dikawasan wisata dengan tampilan virtual 3D.Model
3D dari setiap lokasi wisata turis yang dibuat dengan
menggunakan aplikasi Blender 3D Modeling, tampil
dalam aplikasi yang dibuat dengan Unity 3D
Engine.Proses Rekayasa Perangkat Lunak (RPL)
prototyping model yang merupakan metodologi yang
digunakan dalam penelitian ini.Hasil aplikasi tersebut
memungkinkan pengguna untuk mengetahui sejarah dan bangunan di Museum Monumen Nasional, dan wisatawan dapat menjelajahi virtual 3D dengan menggunakan smartphone berbasis android.

Kata kunci-Monumen Nasional, Turis Virtual, Android, Virtual Reality, Unity.

\section{PENDAHULUAN}

Saat ini banyak objek wisata yang bermunculan diberbagai tempat, namun sebagian besar hanya berupa tempat rekreasi hiburan keluarga yang kurang memberikan nilai pendidikan bagi para pengunjungnya.Sementara objek wisata seperti (Museum) Monumen Nasional yang mempunyai nilai sejarah tinggi justru tidak banyak kita jumpai, dan dari waktu ke waktu pengunjung Monumen Nasional semakin menurun. Untuk mengatasi keadaan yang demikian, maka perlu diadakan usaha-usaha penyampaian informasi dan dokumentasi yang dikemas dengan menarik mengenai informasi tentang Monumen Nasional berupa Aplikasi Virtual Reality[1], [2].Virtual reality atau yang disebut dengan realitas maya adalah teknologi yang memungkinkan pengguna bisa berinteraksi terhadap objek nyata yang disimulasikan menggunakan komputer[3]. Virtual memory sebenarnya adalah lingkungan/ objek yang hanya ada dalam imajinasi yang mampu membangkitkan suasana 3 dimensi sehingga membuat pengguna seolah-olah terlibat secara fisik[4].

Tur virtual adalah simulasi lokasi yang ada, biasanya terdiri dari rangkaian video atau gambar foto. Ini juga dapat menggunakan elemen multimedia lainnya seperti efek suara, musik, narasi, dan teks[5]. Hal ini dibedakan dari penggunaan siaran langsung untuk mempengaruhi tourism [6]. Merancang, memodelkan, dan mengembangkan materi-materi dari tur virtual adalah langkah awal untuk membuat Implementasi Virtual Reality, seperti merancangkan bangunan pada peta, Pembuatan aplikasi tata ruang, perancangan website, pemodelan virtual reality, dan pengembangan museum virtual reality[7].Simulasi 3D virtual reality dilakukan untuk langkahmenguji dari hasil membuat rancangan implementasi virtual (langkah awal)[8]. Setelah tahap uji coba simulasi 3D meneliti bagaimana melestarikan, dan mempertahankan 
potensi virtual reality yang berbasis Smartphone Android yang menggunakan Unity 3D dengan metode Blended Realities[9], [10]. Untuk selanjutnya terkait Implementasi Tur virtual Monumen Nasionalakan menjadi bahasan utama dalam penelitian ini dengan membuat sebuah terapan Virtual Reality menggunakan Unity 3D berbasis Android.

Rumusan masalah yang dapat dirangkum dari pengidentifikasi masalah diatas adalah bagaimana membuat Tur Virtual Monas menggunakan unity 3D.

Dalam membangun aplikasiini diperlukan adanya batasan agar tidak menyimpang dari apa yang direncanakan sehingga tujuan dari aplikasiini dapat tercapai. Batasan masalah yang diperlukan dalam aplikasi ini adalah :

1. Perancangan aplikasiyang dibuat hanya untuk satupengguna.

2. Aplikasiini dirancang untuk dimainkan secara offline.

3. Aplikasi yang digunakan dalam pembuatan tur virtual ini menggunakan unity 3D.

Tujuan dari pembuatan tur virtual ini adalah sebagai berikut:

1. Meningkatkan minat untuk menambah wawasan akan sejarah, karena untuk saat ini wawasan akan sejarah sangat minim peminat atau wisatawan yang berkunjung.

2. Menciptakan simulasi dan Aplikasi Engine yang menarik dan memikat minat pengunjung wisatawan.

3. Turut serta menghasilkan karya dibidangTeknologi Multimedia.

\section{METODE PENELITIAN}

\subsection{AlgoritmaGreedy}

Algoritmagreedy dilakukan dengan cara mengambil contoh persoalan seperti yang mensimulasikan cara kerja algoritmagreedy untuk mencapai jalur terpendek dari titik 77 (MN) ke titik 137 (CM). Dalam simulasi yang dilakukan dijelaskan langkah -perlangkahcara kerja dari algoritmagreedy.

Untuk mencapai jalur terpendek dari titik 77 (MN) ke titik 137 (CM) seperti garis berwarna biru yang merupakan jalur terpendek menuju titik $137(\mathrm{CM})$ dari titik $77(\mathrm{MN})$, yang didapat dari hasil hitung manual dari graf.Langkah selanjutnya mencari jalur terpendek dengan menggunakan algoritmagreedy.

Berikut langkah - langkah AlgoritmaGreedy yang diterapkan:

1. Periksa apakah titik saat ini adalah titik awal.

2. Periksa apakah titik saat ini adalah titik tujuan.

3. Periksa titik yang terhubung dengan titik saat ini.

4. Periksa apakah titik selanjutnya adalah titik tujuan, jika bukan lanjut ke langkah.

5. Cari nilai local maximum ke titik selanjutnya.

6. Tandai titik sekarang sebagai titik yang telah dilalui, dan pindah ke local maximum yang telah ditentukan.
7. Periksa apakah titik selanjutnya sudah pernah dilalui, jika pernah dilalui titik tidak akan dipilih dan mundur ketitik sebelumnya.

8. Kembali ke langkah (1) sampai titik tujuan ditemukan. Jika menerapkan langkah-langkah di atas untuk menemukan rute terpendek dari persoalan graf yaitu dari titik $77(\mathrm{MN})$ ke titik 137 (CM) maka akan didapat pergerakan.

\subsection{Informasi Umum}

Tur Virtual yang dibuat yaitu Virtual yang bertujuan untuk memperkenalkan objek wisata di Monumen Nasional yang dimana pemain menelusuri apa saja yang ada di sekitaran dan di dalam Monumen Nasional. Setiap virtual objek memiliki penjelasan tentang sebuah objek wisata dan bangunan 3D.

\subsubsection{Target}

Tur Virtual pengenalan objek wisata Monumen Nasional ini yang akan dibuat ditargetkan untuk semua kalangan terutama wisatawan yang belum pernah berkunjung ke Monumen Nasional guna mencaritahu informasi tentang Monumen Nasional.

\subsubsection{Keunikan Tur Virtual}

Keunikan Tur Virtual ini yaitu sebagai media pengenalan objek wisata yang ada di daerah Monumen Nasional.Tur Virtual ini lebih sederhana dan bersifat edukasi dapat memberikan sebuah informasi tentang pengenalan objek wisata Monumen Nasional.

\subsubsection{Virtual Play}

Pada awal scene pengguna akan masuk ke tampilan Tur Virtual. Dalam tampilan Tur Virtual terdapat tombol mulai, info, pengaturan, dan keluar. Pada tampilan mulai akan langsung masuk ke dalam Tur Virtual. Kemudian pengguna akan memasuki objek Monumen Nasional, pengguna juga dapat melihat dan mendengarkan tentang sejarah yang ada di Monumen Nasional tersebut serta bisa melihat objek 3 Dimensi.

\subsubsection{Teknologi Yang Digunakan}

1. Bahas Pemrograman : C\#, Java Script

2. Aplikasi Engine : Unity 3D

3. Software Pembangun 3D :Sketchup .

4. Sistem Operasi : Windows 8

5. Spesifikasi computer yang digunakan Processor : Intel(R) Celeron(R) CPU 1007U @ 1.50GHz 1.50GHz. RAM : $2 \mathrm{~GB}$ 


\subsubsection{Alur Perancangan Aplikasi}

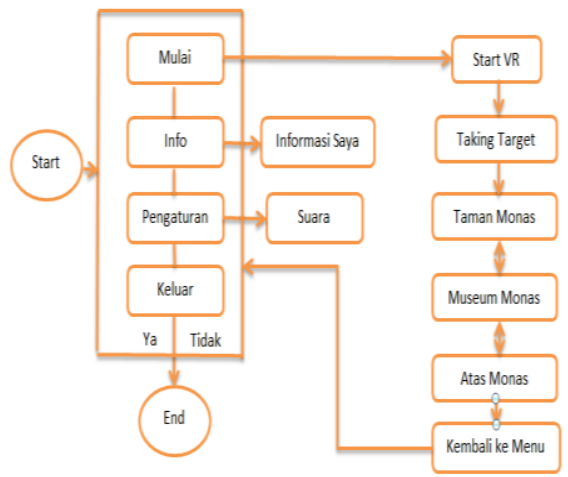

Gambar 1. Alur Perancangan Aplikasi

1. Pada saat user atau pengguna membuka aplikasi virtual tampilan pertama yaitu menu utama. Pada menu utama user atau pengguna dihadapkan oleh beberapa menu seperti : mulai, info, pengaturan dan keluar.

2. Jika user mengklik mulai maka user atau pengguna akan masuk ke dalam virtual reality monumen nasional. Ditahap ini user atau pengguna bisa berkeliling monumen nasional dan bisa melihat ke puncak cawan monas.

3. Jika user mengklik button info maka berupa tampilan profile data pembuat aplikasi.

4. Pengaturan berisi mengenai pengaturan untuk suara pada saat menjelajahi virtual monas.

\subsubsection{Storyboard Aplikasi}

Tabel 1 Storyboard Aplikasi

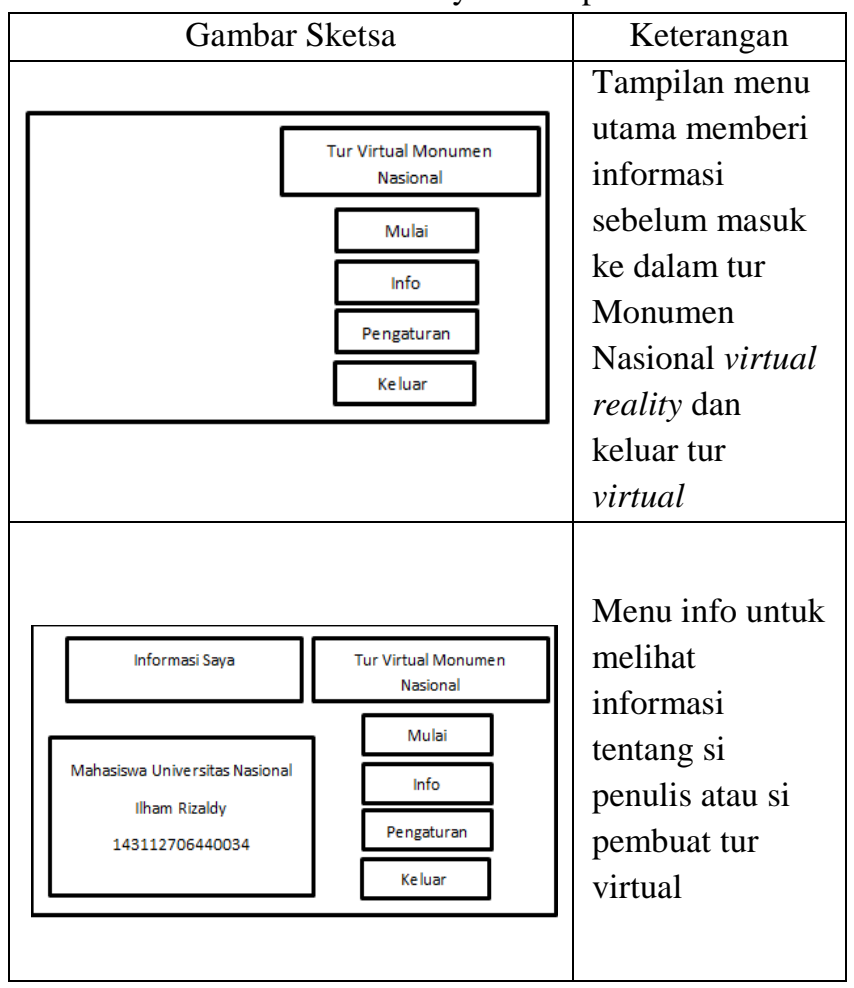

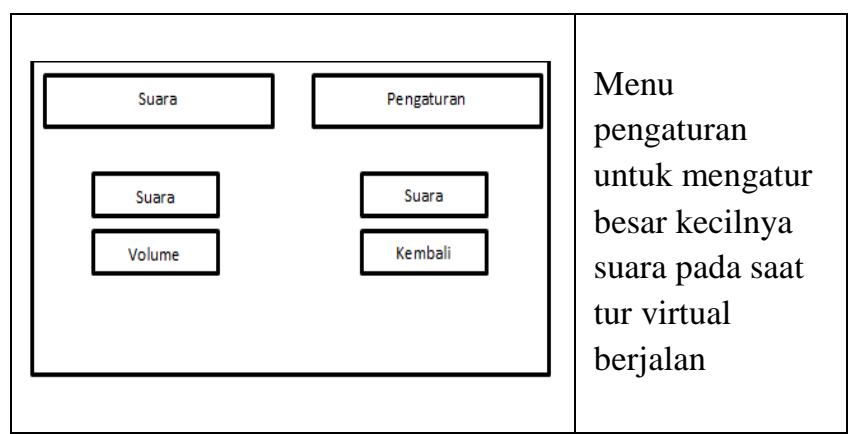

\section{HASIL DAN PEMBAHASAN}

\subsection{Implementasi}

Implementasi ini merupakan tahapan untuk mengubah hasil dari rancangan sistem menjadi bentuk nyata, Dalam hal ini berupa aplikasi Tur Virual yang berjalan pada platform android dengan menggunakan metode AlgoritmaGreedy.

\subsubsection{Scene Menu Utama}

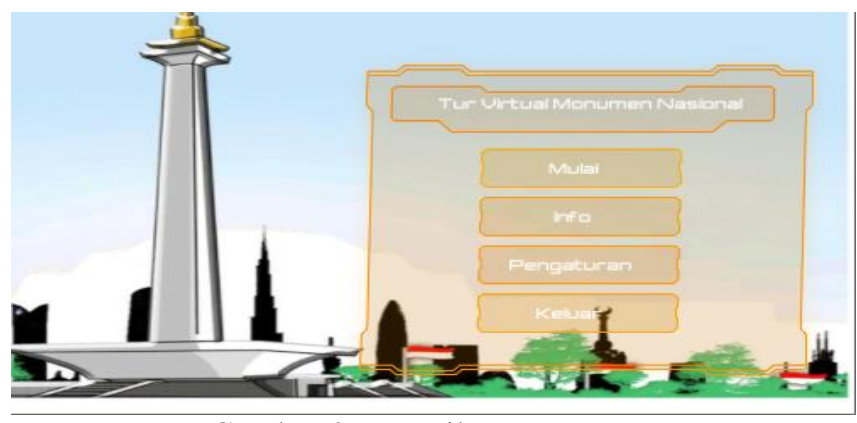

Gambar 2. Tampilan Menu Utama

Tampilan menu utama yaitu dimana tampilan utama dari aplikasi tur virtual ini.Di dalam halaman utama ini terdiri dari beberapa tombol yang dapat diakses untuk pengguna, yaitu button mulai, info, pengaturan dan keluar.

\subsubsection{Scene Info}

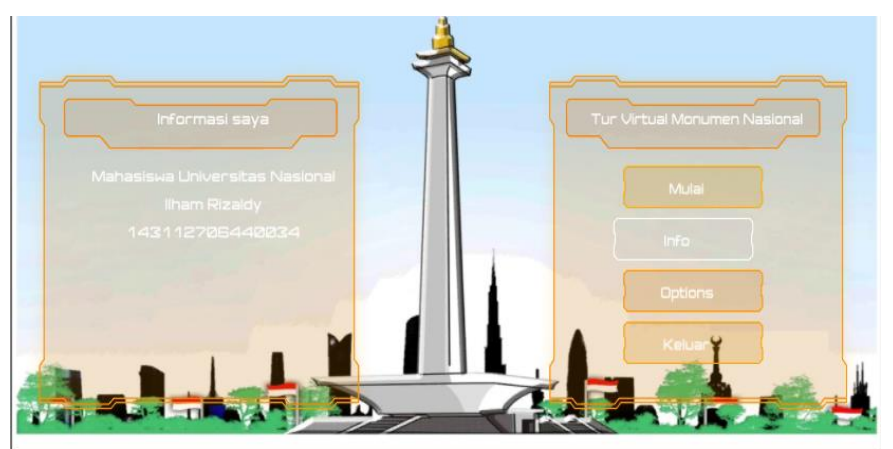

Gambar 3. Tampilan Menu Informasi

Tampilan Info ini merupakan tampilan yang berisi data pembuat atau pengembang suatu aplikasi tur virtual Monumen Nasional. 


\subsubsection{Scene Pengaturan}

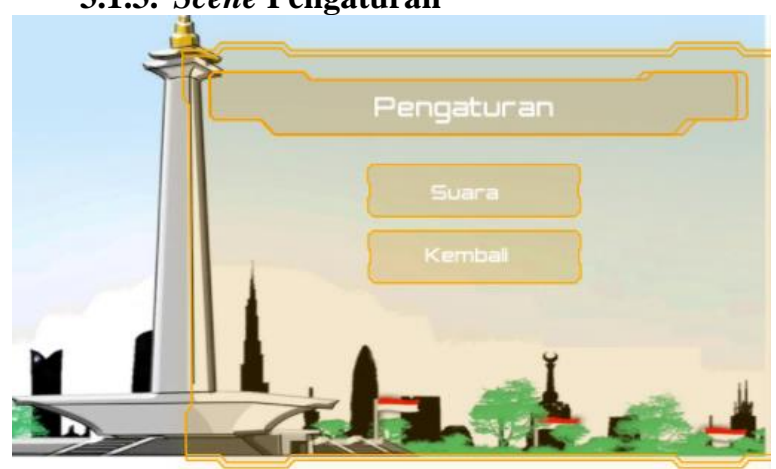

Gambar 4. Tampilan Menu Pengaturan

Tampilan menu pengaturan ini guna untuk user atau pengguna bisa mengkonfigurasi besar kecilnya suara yang ada dalam tur virtual Monumen Nasional.

\subsubsection{Scene Taman Monas}

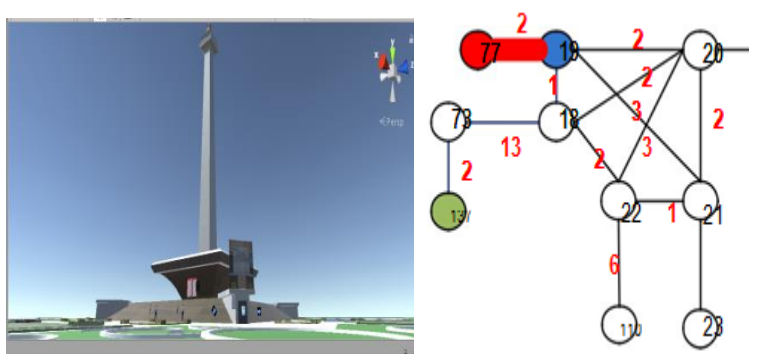

Gambar 6 . Tampilan Taman Monas dan Langkah Greedy

Tampilan taman monas disini user bisa melihat sekitaran taman monas dan pemandangan sebuah objek Monumen Nasional yang terpampang sangat tinggi yang indah dengan diiringi dubbing penjelesan sejarah monas.

Mulai dari titik awal (titik 77) periksa apakah titik saat ini merupakan titik awal, dan apakah titik saat ini merupakan titik tujuan.Ambil seluruh titik yang dapat dikunjungi dari titik saat ini dan periksa apakah titik berikutnya merupakan titik tujuan, jika bukan ambil nilai local maximum dari titik yang terhubung.Local maximum yang dipilih adalah titik 19, karena jarak titik 19 adalah nilai yang palingdekat dari titik 77 .

\subsubsection{Scene Dalam Museum Monas}

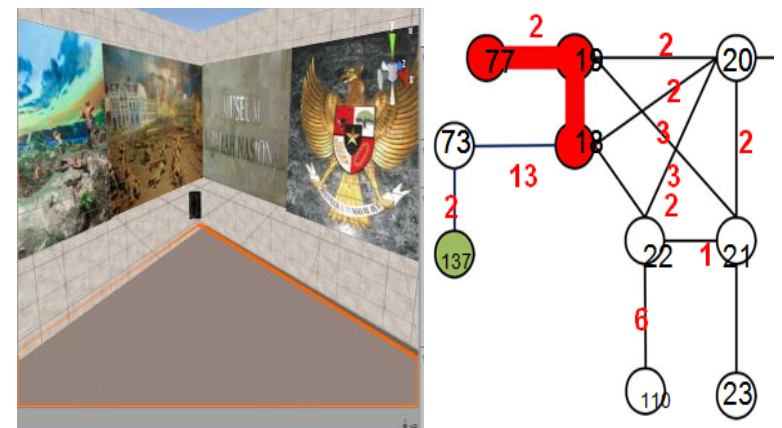

Gambar 7. Tampilan Dalam Museum Monas dan Langkah Greedy
Tampilan dalam museum ini berupa diorama ilustrasi gambaran sejarah masa penjajahan kolonial user bisa melihat sekeliling diorama yang ada didalam museum monas yang diiringi penjelasan sejarah apa saja yang ada di gambaran diorama.

Tandai titik sekarang sebagai titik yang telah dilalui, dan pindah ke localmaximum yang telah di tentukan yaitu 18 dan periksa apakah titik selanjutnyasudah pernah dilalui, jika pernah dilalui titik tidak akan dipilih dan mundur ketitik sebelumnya. Karena titik selanjutnya belum pernah dilalui dan juga bukan merupakan titik tujuan maka ulangi langkah seperti diawal, yaitu dari titik saat ini titik 18 ambil seluruh titik yang dapat dikunjungi dari titik saat ini dan periksa apakah titik berikutnya merupakan titik tujuan, jika bukan ambil nilai local maximum dari titik yang terhubung

\subsubsection{Scene Atas Monas}
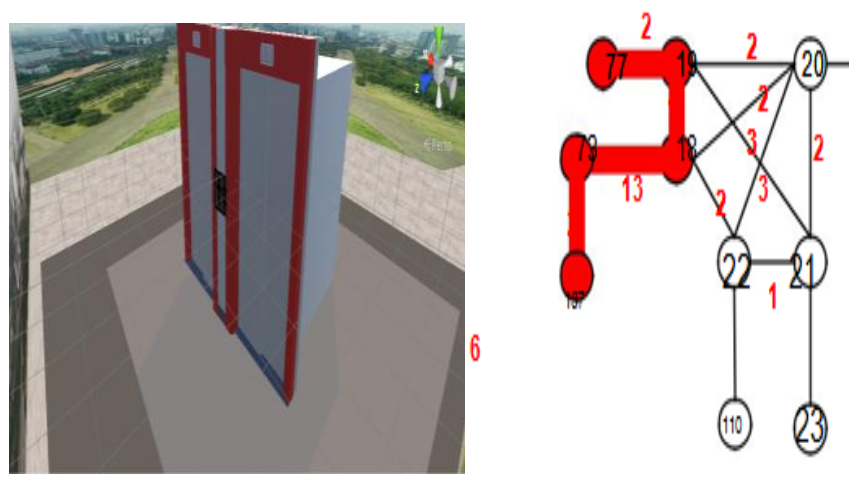

Gambar 8. Tampilan Atas Monas dan Langkah Greedy

Tampilan atas monas ini dimana user bisa melihat ilustrasi dimana user seakan berada diatas monas dan bisa melihat pemandangan keindahan kota Jakarta saat berada dipuncak atas monas.

Tandai titik sekarang sebagai titik yang telah dilalui, dan pindah ke localmaximum yang telah di tentukan yaitu 73 dan periksa apakah titik selanjutnyasudah pernah dilalui, jika pernah dilalui titik tidak akan dipilih dan mundur ketitik sebelumnya. Karena titik selanjutnya belum pernah dilalui dan juga bukan merupakan titik tujuan maka ulangi langkah seperti diawal. Dari titik saat ini yaitu titik 73 periksa apakah titik selanjutnya adalah titik tujuan.jika titik berikutnya merupakan titik tujuan maka pindah ketitik tersebut

Hasil akhir yang didapat sebagai jarak terpendek dari titik awal (MN) ke titik tujuan 137 (CM) adalah 77-19-18-73-137 dengan total jarak yg didapat $2+1+13+2=18$.

\subsection{Pengujian Aplikasi}

Dalam analisa pengujian sistem dilakukan menggunakan 3 smartphone dengan sistem operasi android.Untuk smartphone pertama yaitu berspesifikasi rendah, Smartphone kedua berspesifikasi sedang dan yang ketiga berspesifikasi tinggi. 
Pengujian Tingkat Kecepatan Tur Virtual di Smartphone Tabel 2 Spesifikasi Smartphone Spesifikasi Smartphone 1

\begin{tabular}{|l|l|}
\hline \multicolumn{2}{|c|}{ Spesifikasi Smartphone 1 } \\
\hline Merk Smartphone & Samsung J1 2015 \\
\hline RAM & 512MB \\
\hline Sistem Operasi & OS, v4.4 (KitKat) \\
\hline \multicolumn{2}{|c|}{ Tabel 3 Spesifikasi Smartphone } \\
\hline \multicolumn{2}{|c|}{ Spesifikasi Smartphone 2 } \\
\hline Merk Smartphone & Asus Zenfone 2 \\
\hline RAM & 2GB \\
\hline Sistem Operasi & OS, v5.0 (Lollipop) \\
\hline \multicolumn{2}{|c|}{ Table 4 Spesifikasi Smartphone. } \\
\hline \multicolumn{2}{|c|}{ Spesifikasi Smartphone 3 } \\
\hline Merk Smartphone & Xiaomi 4 Prime \\
\hline RAM & 3 GB \\
\hline Sistem Operasi & OS, v6.1 (Marshmallow) \\
\hline
\end{tabular}

Dari table diatas spesifikasi smartphone yang digunakan baik untuk tur virtual ini menggunakan RAM yang > $2 \mathrm{~GB}$.

\subsubsection{Pengujian Tingkat Kecepatan Tur Virtual di Smartphone}

Tabel 5 Tingkat Kecepatan di Smartphone

\begin{tabular}{|c|c|c|c|}
\hline Pergantian Scene & $\begin{array}{c}\text { Smart } \\
\text { Phone1 }\end{array}$ & $\begin{array}{c}\text { Smart } \\
\text { Phone2 }\end{array}$ & $\begin{array}{c}\text { Smart } \\
\text { Phone3 }\end{array}$ \\
\hline & 1 Detik & 1 Detik & 1 Detik \\
\hline & 1 Detik & 1 Detik & 1 Detik \\
\hline & $\begin{array}{c}1.20 \\
\text { Detik }\end{array}$ & $\begin{array}{c}1.20 \\
\text { Detik }\end{array}$ & 1 Detik \\
\hline & $\begin{array}{c}1 \text { detik } \\
1 \text { Detik }\end{array}$ & 1 Detik & $\begin{array}{c}\text { Detik } \\
\text { Detik }\end{array}$ \\
\hline
\end{tabular}

Dari pengujian diatas, bahwa tingkat kecepatan masingmasing smartphone memiliki tingkat kecepatan yang berbeda namun kecepatan yang dominan untuk virtual scene ini menggunakan 3 smartphone yang berspesifikasi tinggi.

\subsection{Parameter Pengujian}

Parameter ini membahas pengujian dan evaluasi pada aplikasi yang dikembangkan.Pengujian yang dilakukan adalah pengujian terhadap kebutuhan fungsionalitas sistem dan kegunaan sistem. Pengujian fungsionalitas mengacu pada kasus penggunaan pada bab tiga. Pengujian kegunaan program dilakukan dengan mengetahui tanggapan dari pengguna terhadap sistem. Hasil evaluasi menjabarkan tentang rangkuman hasil pengujian pada bagian akhir bab ini.

\section{Tabel 6 Kuesioner}

\begin{tabular}{|c|c|c|}
\hline No. & Parameter & Skala Nilai (1-5) \\
\hline 1 & Apakah Anda Pernah ke Monas & Pernah/Tidak \\
\hline 2 & Immersive dari Lingkungan Tur Virtual & \\
\hline 3 & Aplikasi Ini Nyaman Untuk digunakan & \\
\hline \multicolumn{3}{|c|}{ Tingkat Kepuasan Skenario Tur Virtual Monas } \\
\hline \multicolumn{3}{|c|}{ Situasi Taman Monas } \\
\hline 4 & > Apa Anda Merasa Kesulitan & \\
\hline 5 & > Apakah Aplikasi Ini Terasa Nyata & \\
\hline 6 & $>$ Apakah Anda Merasa Terhibur & \\
\hline \multicolumn{3}{|c|}{ Situasi Museum Nasional } \\
\hline 7 & $>$ Apa Anda Merasa Kesulitan & \\
\hline 8 & > Apakah Aplikasi Ini Terasa Nyata & \\
\hline 9 & > Apakah Anda Merasa Terhibur & \\
\hline \multicolumn{3}{|c|}{ Situasi Cawan Monas } \\
\hline 10 & $>$ Apa Anda Merasa Kesulitan & \\
\hline 11 & > Apakah Aplikasi Ini Terasa Nyata & \\
\hline 12 & Apakah Anda Merasa Terhibur & \\
\hline
\end{tabular}

\subsubsection{Hasil Kuesioner}

Pengisian kuesioner melibatkan 4 orang Mahasiswa Teknik Informatika.Pengisi kuesioner terdiri dari 1 pria dan 3 wanita.Pengguna melakukan pengujian terhadap aplikasi sesuai dengan poin penilaian pada kuesioner. Setiap poin penilaian memiliki skala nilai 1 sampai dengan 5 dengan keterangan 1 adalah buruk sekali, 2 adalah buruk, 3 adalah cukup puas, 4 adalah puas, dan 5 adalah puas sekali. Berikut adalah hasil nilai rata-rata dari kuesioner dapat dilihat pada Tabel 7.

Tabel 7 Hasil Kuesioner

\begin{tabular}{|c|c|c|}
\hline No. & Parameter & Skala Nilai (1-5) \\
\hline 1 & Apakah Anda Pemah ke Monas & Pemah/Tidak \\
\hline 2 & Immersive dari Lingkungan Tur Virtual & 3335 \\
\hline 3 & Aplikasi Ini Nyaman Untuk digunakan & 3444 \\
\hline \multicolumn{3}{|c|}{ Tingkat Kepuasan Skenario Tur Virtual Monas } \\
\hline \multicolumn{3}{|c|}{ Situasi Taman Monas } \\
\hline 4 & $>$ Apa Anda Merasa Kesulitan \\
\hline 5 & $>$ Apakah Aplikasi Ini Terasa Nyata & 3222 \\
\hline 6 & $>$ Apakah Anda Merasa Terhibur & 3444 \\
\hline \multicolumn{3}{|c|}{ Situasi Museum Nasional } \\
\hline 7 & $>$ Apa Anda Merasa Kesulitan \\
\hline 8 & $>$ Apakah Aplikasi Ini Terasa Nyata \\
\hline 9 & $>$ Apakah Anda Merasa Terhibur & 3455 \\
\hline \multicolumn{3}{|c|}{ Situasi Cawan Monas } \\
\hline 10 & $>$ Apa Anda Merasa Kesulitan & 3333 \\
\hline 11 & $>$ Apakah Aplikasi Ini Terasa Nyata & 3343 \\
\hline 12 & $>$ Apakah Anda Merasa Terhibur & 2444 \\
\hline
\end{tabular}

\subsubsection{Hasil Perolehan Tingkat Kepuasan}

Fitur yang membantu uji coba ini adalah Feedback yaitu untuk mengukur tingkat kepuasan pengguna.Dapat dilihat pada tabel bahwa tingkat kepuasan pengguna memiliki sensasi saat menggunakan aplikasi tur virtual. 
Berikut adalah hasil perolehan tingkat kepuasan pengguna pada setiap objek virtual lingkungan yang dapat dilihat pada tabel 8.

Tabel 8 Hasil Perolehan Tingkat Kepuasan

\begin{tabular}{|c|c|c|c|c|}
\hline No. & Nama & Objek & Result & Hasil \\
\hline \multirow{3}{*}{1} & \multirow{3}{*}{ Arbi } & Taman Monas & 3 & \multirow{3}{*}{$\begin{array}{l}\text { CUKUP } \\
\text { PUAS }\end{array}$} \\
\hline & & Museum Monas & 3 & \\
\hline & & Cawan Monas & 3 & \\
\hline \multirow{3}{*}{2} & \multirow{3}{*}{ Nadia } & Taman Monas & 3 & \multirow{3}{*}{ PUAS } \\
\hline & & Museum Monas & 4 & \\
\hline & & Cawan Monas & 4 & \\
\hline \multirow{3}{*}{3} & \multirow{3}{*}{ Christin } & Taman Monas & 4 & \multirow{3}{*}{ PUAS } \\
\hline & & Museum Monas & 3 & \\
\hline & & Cawan Monas & 4 & \\
\hline \multirow{3}{*}{4} & \multirow{3}{*}{ Bella } & Taman Monas & 4 & \multirow{3}{*}{ PUAS } \\
\hline & & Museum Monas & 3 & \\
\hline & & Cawan Monas & 4 & \\
\hline
\end{tabular}

\subsubsection{Grafik Tingkat Kepuasan dan ImmersivePengguna}

Hasil lain dari kuesioner adalah tingkat immersive dan tingkat kepuasan penggunaan aplikasi. Immersive atau tingkat sensasi nyata yang dirasakan pengguna, mempengaruhi kondisi indra pengguna agar merasakan bahwa simulasi yang sedang dijalankan benar-benar terasa nyata. Nilai kepuasan dan immersive pengguna bisa dilihat pada Gambar Pada Grafik tersebut, dapat disimpulkan bahwa rata-rata pengguna memberikan nilai 3 atau cukup setuju pada kepuasan yang diberikan, dan memberikan nilai 4 atau puas pada immersive yang dirasakan gambar 9 .

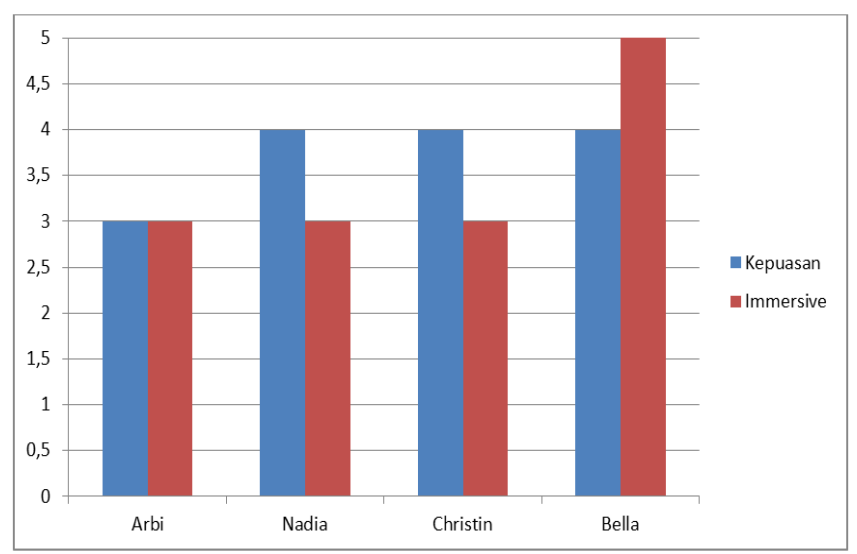

Gambar 9 Grafik Tingkat Kepuasan dan Immersive Pengguna.

\section{KESIMPULAN DAN SARAN}

VirtualScene ini secara keseluruhan berdasarkan pengujian tingkat kecepatan aplikasi di smartphone telah berhasil dijalannkan. Serta menghasilkan Algoritma Greedy yang mengatur keseluruhan sistem virtual. Dan dari hasil pengujian aplikasi Tur Virtual Monumen Nasional berbasis virtual reality ini dapat menjadi salah satu alternatif sebagai media promosi dalam membantu memajukan wisata sejarah di Indonesia.Menciptakan simulasi dan Aplikasi Engine yang menarik dan memikat minat pengunjung wisatawan. Turut serta menghasilkan karya dibidangTeknologi Multimedia.

\section{Ucapan Terimakasih}

Terimakasih kepada Allah SWT, dan kepada Dosen pembimbing telah membimbing saya sehingga saya bisa dapat menyelesaikan penulisan Jurnal ini dengan baik.

\section{DAFTAR PUSTAKA}

[1] N. Hnoohom, "Virtual reality-based smartphone application for animal exposure," pp. 0-5, 2017.

[2] D. Huxpxuwl et al., "01[hg 5hdolw lq 7kh' 9luwxdo 5rrp \$uudqjhphqw," pp. 303-306, 2017.

[3] Y. Nassen, "3D modelling based on virtual reality," pp. 399-402, 2016.

[4] M. C. Moreira and M. A. B. Rodrigues, "Development of mobile virtual application to increase consciousness and relaxation of the pelvic floor muscles," pp. 4-5, 2017.

[5] W. Zheng, L. Feng, B. Liu, P. Fu, and J. Qiao, "Development of Virtual Laboratory Application Structure in Android Cellphone for Distance Learning."

[6] C. De, N. Aguirre, and A. Aim, "Augmented Reality applied in Tourism Mobile Applications," pp. 120-125.

[7] F. J. R. R, C. Science, D. M. I. College, and A. A. Reality, "Word Recognition Incorporating Augmented Reality For Linguistic E-Conversion,” pp. 2106-2109, 2016.

[8] I. Prazina, V. Okanovic, K. Balic, and S. Rizvic, "Usage of Android device in interaction with 3D virtual objects," pp. 244-246, 2017.

[9] E. Patti et al., "Information Modeling for Virtual and Augmented Reality," no. June, 2017.

[10] I. E. Nugraha and T. W. Sen, "Assembly Instruction With Augmented Reality On Android Application 'Assembly With AR,"” pp. 32-37, 2017. 